\title{
Evaluation of the performance of two carbodiimide-based cyanine dyes for detecting changes in mRNA expression with DNA microarrays
}

\author{
Naoki Kimura ${ }^{1}$, Taka-aki Tamura ${ }^{2}$, and Masahiro Murakami ${ }^{1}$
}

BioTechniques 38:797-806 (May 2005)

\begin{abstract}
Microarrays have been extensively used to investigate genome-wide expression patterns. Although this technology has been tremendously successful, several practical issues would benefit from improvements in design. Here we describe a novel, efficient labeling methodology that uses carbodiimide-linked cyanine dyes to directly chemically label cDNA derived from mouse total RNA. Using this protocol, it takes only $10 \mathrm{~min}$ at $70^{\circ} \mathrm{C}$ to complete the $\mathrm{cDNA}$ labeling reaction. The directly labeled cDNAs can then be hybridized to 70-mer mouse oligonucleotide arrays for expression profiling studies. Microarray analyses indicate that these cDNAs are uniformly labeled and produce higher signal intensities than conventional enzymatic direct labeling methods and comparable signal intensities to those obtained by conventional indirect labeling methods. Furthermore, verification of our microarray data using a reverse transcription PCR (RT-PCR) method indicates good agreement between the two methods. Thus, we conclude that our simplified cyanine-carbodiimide labeling method, which does not rely on the incorporation of modified nucleotides, will provide a reliable, quicker, and potentially cheaper alternative to established labeling techniques for gene expression analyses.
\end{abstract}

\section{INTRODUCTION}

Recently, hybridization analysis using DNA microarray technology has become a fundamental technique for evaluating the expression levels of thousands of genes in a variety of cells and tissues simultaneously (1-8). In a typical microarray experiment using oligonucleotide or cDNA arrays, two mRNA samples to be compared are reverse-transcribed into cDNA, labeled using two different fluorophores (usually $\mathrm{Cy}^{\mathrm{TM}} 5$ and $\mathrm{Cy} 3$ dyes), and then hybridized simultaneously to a glass slide on which the oligonucleotides or cDNA are immobilized on the surface. The fluorescence signal intensity for each DNA spot is directly related to the level of gene expression, and a comparison of the resulting signal intensity ratios between the two samples directly reflects differences in their expression. One of the key components of microarray assays, which should quantitatively reflect the abundance of different messenger RNAs (mRNAs) in the two samples to be compared, is the method used to fluorescently label the target nucleic acids $(1,3-6)$. Several different protocols for the fluorescent labeling of cDNA by enzymatic or chemical methods have been described (1,3-6); however, all of these methods are time-consuming (on the order of hours) and are often rather expensive (requiring fluorescently labeled, aminoallyl labeled, or biotinylated triphosphate nucleotides and enzymes). In addition, inconsistencies between microarray data and the results of Northern blot or reverse transcription PCR (RT-PCR) analyses raise doubts about the quantitative aspect of microarray data $(9,10)$. This issue remains of great concern when using DNA microarrays as a tool for gene discovery. Recently, more rapid and reliable DNA and RNA chemical labeling methods utilizing radicalgenerating coordination complexes and platinum compounds have also been reported $(11,12)$. While these methods circumvent some of the problems with previously reported labeling methods, several practical issues would still benefit from further improvements in design.

Here we describe an alternative method for chemically labeling cDNA that uses a cyanine-linked carbodiimide $(-\mathrm{N}=\mathrm{C}=\mathrm{N}-)$ monofunctional group. Carbodiimides are reactive functional groups that are used in DNA or RNA modification $(13,14)$. For several years, our laboratory has been developing a carbodiimide-based DNA labeling system (15) and a polycarbodiimidecoated glass slide for use as a DNA microarray substrate (16), and the technologies concerning these carbodi-

\footnotetext{
${ }^{1}$ Nisshinbo Industries, Chiba and ${ }^{2}$ Chiba University, Chiba, Japan
} 
imide chemistries have been patented. This direct chemical labeling method is a simple procedure that does not rely on the incorporation of modified nucleotides into the fluorescent labeling reaction and should therefore result in substantial cost-savings and high-quality signal detection for DNA microarrays with good reproducibility.

The goal of the current study was to determine whether two novel carbodiimide-based cyanine dyes developed for this system could be effectively used for labeling with fluorescent dyes as part of an overall DNA microarray protocol. As a result, a reliable method of cDNA labeling using these carbodiimide-generating complexes has been developed that provides a sample preparation time of minutes. Furthermore, the observed data are comparable to those of an RT-PCR methodology for most genes tested. The approach described here provides a novel experimental tool with which to identify targets that produce specific and reproducible hybridization signals in DNA-chip expression profiling approaches.

\section{MATERIALS AND METHODS}

\section{Instruments}

Nuclear magnetic resonance (NMR) spectra were recorded at $270 \mathrm{MHz}$ on a JOEL JNM-GSX270 FT NMR system GSX FT NMR spectrometer (JOEL Ltd., Tokyo, Japan). Infrared (IR) spectra were observed on a FT IR-8200 PC (Shimazu, Kyoto, Japan). Highperformance liquid chromatography (HPLC) analysis ( $\mu$ Bondaspphere, Model C8-300A, 3.9 $\times 150 \mathrm{~mm}$; Waters, Milford, MA, USA) was performed with a gradient of 5\%-100\% acetonitrile in $0.1 \mathrm{M}$ triethylammonium acetate (TEAA), $\mathrm{pH} 7.0$, and a flow rate of 1 $\mathrm{mL} / \mathrm{min}$ over $40 \mathrm{~min}$. A ScanArray ${ }^{\circledR}$ 4000 instrument (Packard BioChip, Billerica, MA, USA) was used to detect the hybridization signals.

\section{Selection and Synthesis of Oligonucleotides}

The oligonucleotide sequences (70 bp) used in this study were selected from the OligoPicker web site (pga. mgh.harvard.edu/oligopicker/) using OligoPicker software (17) and are available on the web site. The web site provides approximately 15,000 specific mouse sense oligonucleotide probe sequences, but we randomly chose 1561 probes that cover a broad spectrum of functionality. All nonmodified oligonucleotides (approximately $0.2 \mu \mathrm{mol}$ ) were synthesized on an ABI PRISM ${ }^{\circledR}$ 3900 DNA synthesizer by a standard phosphoramidite method. A negative control comprising an oligonucleotide probe that is noncomplementary to the mouse sequence was also designed and synthesized.

\section{Preparation of Glass Oligonucleotide Microarrays}

A Pixsys ${ }^{\mathrm{TM}}$ DNA microarray spotter (Cartesian Technologies, Irvine, CA, USA) was used to print arrays of oligonucleotides on CarboStation ${ }^{\mathrm{TM}}$ glass slides (Nisshinbo Industries, Chiba, Japan) (16). Nonmodified oligonucleotides in $3 \times$ standard saline citrate (SSC; total volume of $20 \mu \mathrm{L}$ ) were used for printing [a total of 1794 elements including 40 negative controls and 193 blank spots (buffer only) per slide]. Nonmodified oligonucleotides concentration of $20 \mathrm{pmol} / \mu \mathrm{L}$. After printing, the arrays were UV-irradiated using a UV Stratalinker ${ }^{\circledR} 2400$ (Stratwere printed from 96-well plates at a

agene, La Jolla, CA, USA), treated with a blocking buffer [3\% bovine serum albumin (BSA), $0.2 \mathrm{M} \mathrm{NaCl}, 0.1$ $\mathrm{M}$ Tris- $\mathrm{HCl}, \mathrm{pH} 7.5$, and $0.05 \%$ Triton $^{\circledR}$ $\mathrm{X}-100]$, washed with Tris-EDTA (TE) buffer, $\mathrm{pH}$ 7.2, for $5 \mathrm{~min}$, according to the manufacturer's instructions (16), and dried before storage.

\section{Synthesis of the Cyanine Dyes Containing Carbodiimide Groups}

Cy5- and Cy3-carbodiimide dyes [also known commercially as CarboSpirit ${ }^{\mathrm{TM}}$ dyes; available upon request (e-mail: bio@nisshinbo.co.jp) from Nisshinbo Industries] (Figure 1) were synthesized using commercial reagents. In brief, N-(3-dimethylaminopropyl)$\mathrm{N}^{\prime}$-morpholinopropyl carbodiimide 1 and the Cy5 dye $2 \mathrm{~b}$ were synthesized as previously described $(15,18)$. To a stirring solution of the $\mathrm{Cy} 5$ dye $2 \mathrm{~b}$ (46.6 mg, $41.5 \mu \mathrm{mol})$ in $2 \mathrm{~mL}$ DMF (N,N-dimethylformamide) on ice, $\mathrm{N}$ (3-dimethylaminopropyl)-N'-morpholinopropyl carbodiimide $1(211 \mathrm{mg}$, $830 \mu \mathrm{mol})$ was added dropwise. The mixture was stirred overnight initially at $0^{\circ} \mathrm{C}$ and then at room temperature. Excess diethyl ether was added to the solution, and the resulting precipitate was collected by centrifugation at $12,000 \times g$. The precipitate was dissolved in methanol and then purified by Sephadex ${ }^{\mathrm{TM}}$ LH-20 (Amersham

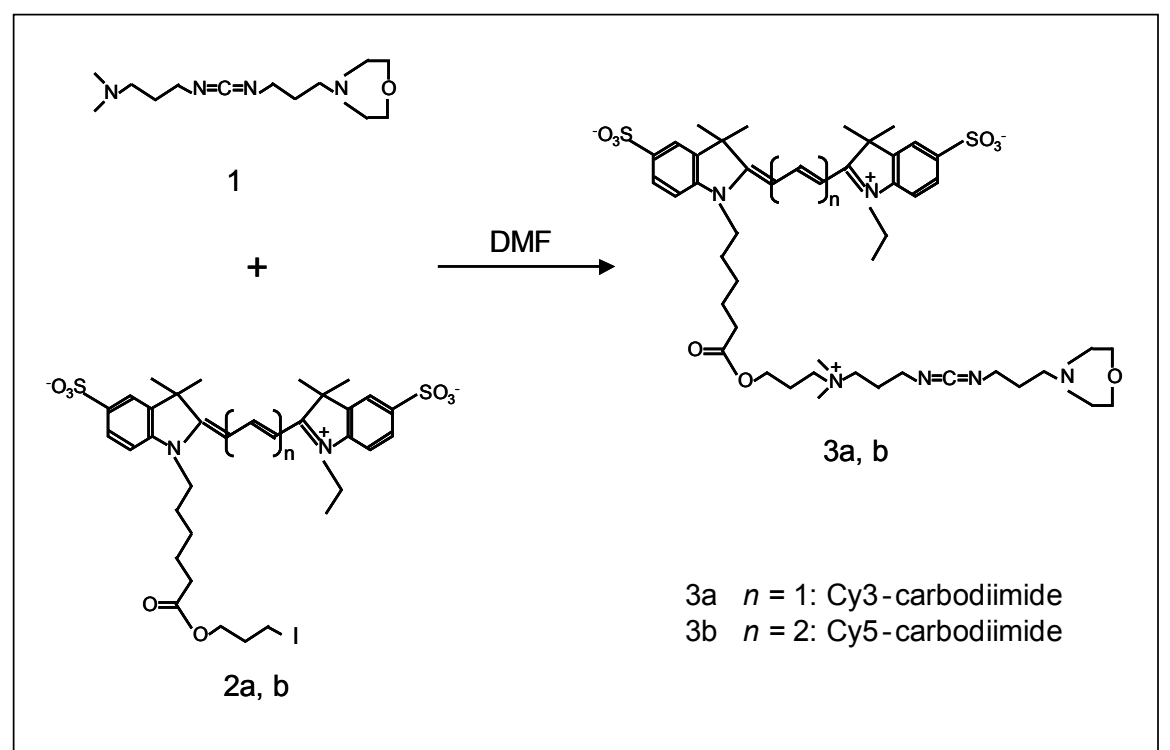

Figure 1. Synthesis of cyanine dye-carbodiimides. Yields were $85 \%$ for the Cy5-carbodiimide and $84 \%$ for the Cy3-carbodiimide. DMF, N,N-dimethylformamide. 
Biosciences, Piscataway, NJ, USA). It was dried under reduced pressure to give $48.3 \mathrm{mg}$ ( $85 \%$ yield) of Cy5carbodiimide $3 \mathrm{~b}$ as a deep-red solid. Characterization data for Cy5-carbodiimide are as follows. HPLC $R_{\mathrm{f}}=14.89$ min; ${ }^{1} \mathrm{H}$ NMR (dimethyl sulfoxide (DMSO)- $d 6$ ]: $\delta 8.35(\mathrm{~m}, 2 \mathrm{H}$, protons of the cyanine bridge), $7.83(2 \mathrm{~d}, J=7.7$ $\mathrm{Hz}, 2 \mathrm{H}), 7.65(\mathrm{~m}, 2 \mathrm{H}), 7.31(\mathrm{~m}, 2 \mathrm{H})$, $6.59(\mathrm{t}, J=7.7 \mathrm{~Hz}, 1 \mathrm{H}$, a proton of the cyanine bridge), $6.30(2 \mathrm{~d}, J=13 \mathrm{~Hz}$, $2 \mathrm{H}$, protons of the cyanine bridge), $4.15(\mathrm{~m}, 4 \mathrm{H}), 3.9(\mathrm{~m}, 4 \mathrm{H}), 3.25[\mathrm{~s}, 6 \mathrm{H}$, $\left.\mathrm{CH}_{2} \mathrm{~N}^{+}\left(\mathrm{CH}_{3}\right)_{2} \mathrm{CH}_{2}\right], 3.0-3.5(\mathrm{~m}, 16 \mathrm{H})$, $2.25\left(\mathrm{t}, \mathrm{J}=7 \mathrm{~Hz}, 2 \mathrm{H}, \mathrm{CH}_{2} \mathrm{COOCH}_{2}\right)$, $1.65\left[\mathrm{~s}, 12 \mathrm{H}, 2\left(\mathrm{CH}_{3}\right)_{2}\right], 1.28(\mathrm{t}, J=7$ $\left.\mathrm{Hz}, 3 \mathrm{H}, \mathrm{CH}_{2} \mathrm{CH}_{3}\right), 1.0-1.9(\mathrm{~m}, 12 \mathrm{H}$, $6 \mathrm{CH}_{2}$ groups). The IR spectrometer indicated a single peak of a carbodiimide group at $2129 \mathrm{~cm}^{-1}$. Cy3 containing a carbodiimide group (Cy3carbodiimide) 3a was also synthesized as described above, with $84 \%$ yield. Characterization data for Cy3-carbodiimide was as follows. HPLC $R_{\mathrm{f}}=13.49$ $\min ;{ }^{1} \mathrm{H}$ NMR (DMSO- $\left.d 6\right): \delta 8.40(\mathrm{t}$, $J=14 \mathrm{~Hz}, 1 \mathrm{H}$, a proton of cyanine bridge), $7.83(\mathrm{~s}, 2 \mathrm{H}), 7.6(2 \mathrm{~d}, 2 \mathrm{H})$, $7.45(\mathrm{~m}, 2 \mathrm{H}), 6.50(\mathrm{~d}, J=14 \mathrm{~Hz}, 2 \mathrm{H}$, protons of cyanine bridge $), 4.10(\mathrm{~m}$, $4 \mathrm{H}), 3.9(\mathrm{~m}, 4 \mathrm{H}), 3.0-3.5(\mathrm{~m}, 16 \mathrm{H})$, $3.1\left[\mathrm{~s}, 6 \mathrm{H}, \mathrm{CH}_{2} \mathrm{~N}^{+}\left(\mathrm{CH}_{3}\right)_{2} \mathrm{CH}_{2}\right], 2.25(\mathrm{t}$, $\left.J=7 \mathrm{~Hz}, 2 \mathrm{H}, \mathrm{CH}_{2} \mathrm{COOCH}_{2}\right), 1.65[\mathrm{~s}$, $\left.12 \mathrm{H}, 2\left(\mathrm{CH}_{3}\right)_{2}\right], 1.28(\mathrm{t}, J=7 \mathrm{~Hz}, 3 \mathrm{H}$, $\left.\mathrm{CH}_{2} \mathrm{CH}_{3}\right), 1.0-2.0\left(\mathrm{~m}, 12 \mathrm{H}, 6 \mathrm{CH}_{2}\right.$ groups). The IR spectrometer indicated a single peak of a carbodiimide group at $2129 \mathrm{~cm}^{-1}$.

\section{Synthesis, Labeling, and Purification of cDNA}

Total RNAs from mouse brain and liver were extracted using TRIzoL ${ }^{\circledR}$ reagent (Invitrogen, Carlsbad, CA, USA), according to the manufacturer's instructions.

Typically, $1-5 \mu \mathrm{g}$ total RNA were used in each of the reverse transcription reactions. Total RNA containing 200 pmol oligo(dT) (12-18 nucleotides in length; Takara, Kyoto, Japan) in RNase-free water was heated to $70^{\circ} \mathrm{C}$ for $10 \mathrm{~min}$ and then incubated on ice for $5 \mathrm{~min}$. The reverse transcription reaction (in a total volume of 20 $\mu \mathrm{L}$ ) included $1 \mu \mathrm{L}$ PowerScript ${ }^{\mathrm{TM}}$ II Reverse Transcriptase (BD Biosci- ences Clontech, Palo Alto, CA, USA), $4 \mu \mathrm{L}$ of $5 \times$ First-Strand buffer, 2 $\mu \mathrm{L}$ dithiothreitol (DTT; $100 \mathrm{mM}$ ), and $2 \mu \mathrm{L}$ of dNTP mixture $(10 \mathrm{mM}$ each dATP, dCTP, dGTP, and dTTP) (Amersham Biosciences). After $1 \mathrm{~h}$ of incubation at $48^{\circ} \mathrm{C}$, the reaction was stopped by heating to $70^{\circ} \mathrm{C}$ for $5 \mathrm{~min}$. RNase H (2 U) was then added. cDNA was purified by ethanol precipitation, rinsed twice with $70 \%$ ethanol, and stored at $-20^{\circ} \mathrm{C}$.

Cy5-carbodiimide dye and $\mathrm{Cy} 3$ carbodiimide dye dissolved in DMSO at a concentration of $5 \mathrm{mM}$ were used for cDNA labeling. cDNA dissolved in distilled water and either $\mathrm{Cy} 3-$ or Cy5-carbodiimide dye solution (final concentration of carbodiimide reagent was $0-2 \mathrm{mM}$ in a DMSO/water ratio of $1: 1$ ) in a final volume of $20 \mu \mathrm{L}$ were incubated at $70^{\circ} \mathrm{C}$ for $3-30 \mathrm{~min}$. 
Table 1. Primers Used for Fluorescent RT-PCR Analysis

\begin{tabular}{|c|c|c|c|}
\hline $\begin{array}{l}\text { GenBank }^{\circledR} \\
\text { Accession No. }\end{array}$ & Gene Name & Primer & Sequence \\
\hline NM_008084 & $\begin{array}{l}\text { Mus musculus similar to glyceralde- } \\
\text { hyde-3-phosphate dehydrogenase }\end{array}$ & $\begin{array}{l}\text { forward } \\
\text { reverse }\end{array}$ & $\begin{array}{l}\text { 5'-ACCCAGAAGACTGTGGATGG-3' } \\
5^{\prime} \text { - ACACATTGGGGGTAGGAACA-3' }\end{array}$ \\
\hline NM_010048 & DiGeorge syndrome protein C & $\begin{array}{l}\text { forward } \\
\text { reverse }\end{array}$ & $\begin{array}{l}\text { 5'-CCTGCTGGTTCTCACTGTCA-3' } \\
5^{\prime} \text {-TTCCCTAGGAAGCTGCTGAA-3' }\end{array}$ \\
\hline NM_008940 & $\begin{array}{l}\text { protease, serine, } 19 \text { (neuropsin); } \\
\text { brain serine protease } 1\end{array}$ & $\begin{array}{l}\text { forward } \\
\text { reverse }\end{array}$ & $\begin{array}{l}\text { 5'-CGGTTCAGCTTCATTCCATT-3' } \\
\text { 5'-CAGTGGGGCTTGTCTTCATT-3' }\end{array}$ \\
\hline NM_020570 & $\begin{array}{l}\text { X-ray repair complementing defective } \\
\text { repair in Chinese hamster cells } 2 \text {; } \\
\text { recA/RAD51 family protein }\end{array}$ & $\begin{array}{l}\text { forward } \\
\text { reverse }\end{array}$ & $\begin{array}{l}\text { 5'-GTCAGAGAAAGTGGGGTGGA-3' } \\
\text { 5'-AAGCTCGGTGGAGTTTAGCA-3' }\end{array}$ \\
\hline NM_017373 & nuclear factor, interleukin 3 , regulated & $\begin{array}{l}\text { forward } \\
\text { reverse }\end{array}$ & $\begin{array}{l}\text { 5'-ATGAGGGTGTAGTGGGCAAG-3' } \\
\text { 5'-GCGGGTGAAGAGAGTTTCTG-3' }\end{array}$ \\
\hline NM_008139 & $\begin{array}{l}\text { guanine nucleotide binding protein, } \\
\alpha_{q} \text { polypeptide; } G \alpha_{q}\end{array}$ & $\begin{array}{l}\text { forward } \\
\text { reverse }\end{array}$ & $\begin{array}{l}\text { 5'-TGTGTGGTTTGTCGTGAGGT-3' } \\
\text { 5'-CACTGAGCGGTGACTTTTGA-3' }\end{array}$ \\
\hline NM_023653 & $\begin{array}{l}\text { wingless-related MMTV integration } \\
\text { site } 2\end{array}$ & $\begin{array}{l}\text { forward } \\
\text { reverse }\end{array}$ & $\begin{array}{l}\text { 5'-TTCAGCTGGCGTTGTATTTG-3' } \\
\text { 5'-CCTTCCTTCCAGCTCTGTTG-3' }\end{array}$ \\
\hline NM_009894 & $\begin{array}{l}\text { cell death-inducing DNA fragmenta- } \\
\text { tion factor, } \alpha \text { subunit-like effector B }\end{array}$ & $\begin{array}{l}\text { forward } \\
\text { reverse }\end{array}$ & $\begin{array}{l}\text { 5'-CTGGAACTCAGCTCCTCCAC-3' } \\
\text { 5'-CAGCAGCTGGAAGAAGTCCT-3' }\end{array}$ \\
\hline NM_010807 & MARCKS-like protein & $\begin{array}{l}\text { forward } \\
\text { reverse }\end{array}$ & $\begin{array}{l}\text { 5'-TCTTGTGCTGTGCCTAGTGG-3' } \\
\text { 5'-TACAGACCTCCCTCCCTCCT-3' }\end{array}$ \\
\hline NM_010247 & thyroid autoantigen $70 \mathrm{kDa}$; Ku p70 & $\begin{array}{l}\text { forward } \\
\text { reverse }\end{array}$ & $\begin{array}{l}\text { 5'-GTCAAGCAAGCTGGAAGACC-3' } \\
\text { 5'-TTCTCCAGCACAATCTGACG-3' }\end{array}$ \\
\hline NM_010343 & glutathione peroxidase 5 & $\begin{array}{l}\text { forward } \\
\text { reverse }\end{array}$ & $\begin{array}{l}\text { 5'-TGGGGATAGCTTGGTTGAAG-3' } \\
\text { 5'-GGCAGAGAGGATGGAGACAG-3' }\end{array}$ \\
\hline NM_007811 & $\begin{array}{l}\text { cytochrome } \mathrm{P} 450,26 \text {, retinoic acid; } \\
\text { retinoic acid hydrolase }\end{array}$ & $\begin{array}{l}\text { forward } \\
\text { reverse }\end{array}$ & $\begin{array}{l}\text { 5'-CGGTTCAGCTTCATTCCATT-3' } \\
\text { 5'-CAGTGGGGCTTGTCTTCATT-3' }\end{array}$ \\
\hline
\end{tabular}

tube (PMT) settings to obtain optimum signal intensities. The resulting images were used to generate Tiff data files. Data analysis was done using QuantArray ${ }^{\circledR}$ software (Packard BioChip) and Microsoft ${ }^{\circledR}$ Excel. Typically, data were normalized to the median. Only those genes with a minimum average signal intensity [(Cy3 plus $\mathrm{Cy} 5) / 2]$ that was at least three times the background noise level in both channels were included in the analysis. The signal intensities arising from negative control oligonucleotide spots were always below this background threshold, which indicated that cross-hybridization was negligible. All statistical analyses and the level of statistical significance of each gene were determined by using the regularized $t$-test statistic (8).
Fluorescently labeled cDNA was purified by ethanol precipitation and a MinElute PCR Purification Kit (Qiagen, Valencia, CA, USA) and then concentrated in a SpeedVac ${ }^{\circledR}$ (TeleChem International, Sunnyvale, CA, USA) and stored at $-20^{\circ} \mathrm{C}$.

The cDNA was also labeled by conventional methodologies. We followed the protocols of the Brown Laboratory (Stanford, CA, USA) for the direct and indirect labeling of cDNA (cmgm.stanford.edu/pbrown) (2). Typically, 1-5 $\mu \mathrm{g}$ total RNA were also used in each of the reverse transcription reactions.

\section{Hybridization and Wash Conditions}

ExpressHyb $^{\mathrm{TM}}$ Hybridization Solution (BD Biosciences Clontech) was added to the labeled cDNA solution $[60 \%(\mathrm{v} / \mathrm{v})$ ExpressHyb hybridization solution; total volume was $40 \mu \mathrm{L}$ ].
The hybridization solution was heated for $2 \mathrm{~min}$ at $95^{\circ} \mathrm{C}$, cooled to room temperature, and centrifuged for 10 $\mathrm{min}$ at $12,000 \times \mathrm{g}$ in a microcentrifuge. The hybridization solution was applied between the slide and the coverslip by capillary action. The slide was incubated overnight at $45^{\circ} \mathrm{C}$ in a closed hybridization cassette. Subsequently, the arrays were washed at room temperature in $2 \times \mathrm{SSC}, 0.1 \%$ sodium dodecyl sulfate (SDS) for $5 \mathrm{~min}, 0.5 \times \mathrm{SSC}$, twice in $0.1 \%$ SDS for $5 \mathrm{~min}$, rinsed briefly twice in $0.9 \% \mathrm{NaCl}$ at $4^{\circ}-10^{\circ} \mathrm{C}$, and dried by centrifugation at $50 \times g$ (CS-15 Centrifuge; Beckman Coulter, Fullerton, CA, USA) for 2 min.

\section{Microarray Data Analysis}

A ScanArray 4000 instrument was used to detect the hybridization signals. Arrays were scanned at $10-\mu \mathrm{m}$ resolution with variable photomultiplier

\section{RT-PCR Analysis}

First-strand cDNA synthesis was performed using $5 \mu \mathrm{g}$ total RNA and PowerScript II reverse transcriptase, according to the manufacturer's instructions. Fluorescent PCR analysis was performed using the Applied Biosystems 7300 Real-Time PCR System (Applied Biosystems, Foster City, CA, USA) and SYBR ${ }^{\circledR}$ Green I (Molecular Probes, Eugene, OR, USA) as previously described $(19,20)$. Amplification reactions consisted of 40 cycles of denaturation at $95^{\circ} \mathrm{C}$ for $15 \mathrm{~s}$, annealing at $60^{\circ} \mathrm{C}$ for $30 \mathrm{~s}$, and extension at $74^{\circ} \mathrm{C}$ for $50 \mathrm{~s}$ using the primers listed in Table 1. Fluorescent signals were obtained once in each cycle by sequential fluorescence monitoring of each sample tube at the end of extension. Cycle thresholds $\left(C_{t} s\right)$ for each gene were obtained 
using the second derivative maximum function for the Applied Biosystems 7300 System SDS Software (Applied Biosystems). Amplifications were repeated for each pair of primers for the cDNA derived from each tissue, and the $C_{t}$ values were averaged. Normalization was performed by subtracting the $\mathrm{C}_{\mathrm{t}} \mathrm{s}$ obtained for the housekeeping gene glyceraldehyde-3-phosphate dehydrogenase (GAPDH) from the $\mathrm{C}_{\mathrm{t}} \mathrm{s}$ of the genes of interest for each sample. An additional normalization was then performed for each primer set by subtracting the $\mathrm{C}_{t} \mathrm{~s}$ derived from a composite cDNA sample from the $C_{t}$ values obtained for each test sample for the same primer pair. The resulting normalized values were used to determine the relative levels of upor down-regulation for each gene.

\section{RESULTS}

\section{Properties of the Carbodiimide Dyes for cDNA Labeling}

We have developed a novel nonenzymatic system for fluorescently labeling nucleic acids. The structures of the cyanine-carbodiimide dyes developed in this work are shown in Figure 1. This system uses a carbodiimide group to label cDNA directly with cyanine dyes via a long linker arm, which reacts with the unpaired imino group of thymine, uracil, or guanine bases in DNA or RNA and forms stable adducts $(13,14)$. The labeling reagent was designed on the basis of previous preliminary model studies showing that a biotin group can be appended to the imino group of M13mp18 single-stranded DNA (ssDNA) and M13mp18 replicative form (RF) DNA via reaction with a carbodiimide group (15).

To routinely label a cDNA sample at a specified desired degree of modification, it is necessary to determine the reaction kinetics. Once the kinetics are known, reaction conditions including reactant concentrations (carbodiimide dye and cDNA), temperature, and time of reaction can be formulated in subsequent studies to yield the desired level of labeling. To assess the reaction kinetics, we obtained cDNAs with varying degrees of carbodiimide modification by reacting a fixed amount of cDNA with varying amounts of carbodiimide compounds at $70^{\circ} \mathrm{C}$ for $10 \mathrm{~min}$. The results for Cy 5 are shown in Figure 2A; essentially identical results were obtained for the Cy3-carbodiimide reagent. The results suggest that low concentrations of carbodiimide reagent do not produce an adequate level of labeling, whereas an excess of carbodiimide reagent inhibits hybridization capability, as assessed by the hybridization signals determined by DNA microarrays. Furthermore, by varying the length of the reaction at $70^{\circ} \mathrm{C}$ at a fixed concentration of 1.2 $\mathrm{mM}$ carbodiimide reagent, we found that labeling went almost to completion after $10 \mathrm{~min}$ of incubation and that the labeling reaction was saturated by 30 min of incubation (Figure 2B). The optimal degree of labeling was found to be $30-50$ bp per molecule of carbodiimide dye.

\section{Homotypic Hybridization Assays}

To determine whether the cyanine carbodiimide reagent-modified nucleic acids could be effectively used as part of an overall DNA microarray protocol, we evaluated the effect on hybridization signals by varying the amount of input total RNA used in labeling reactions. We compared the hybridization signals obtained with this system to those obtained by "gold standard" direct and indirect labeling methodologies that use cyanine-dUTPs, and a combination of aminoallyl-dUTP and N-hydroxysuccinimidyl ester of cyanine dyes, respectively. To exclude experimental variability caused by sample input, the same RNA sample from mouse brain was used for all target preparations. Furthermore, the oligonucleotide arrays used for these comparative assays were all derived from the same qualitycontrolled spotting batch.

Varying amounts of mouse brain

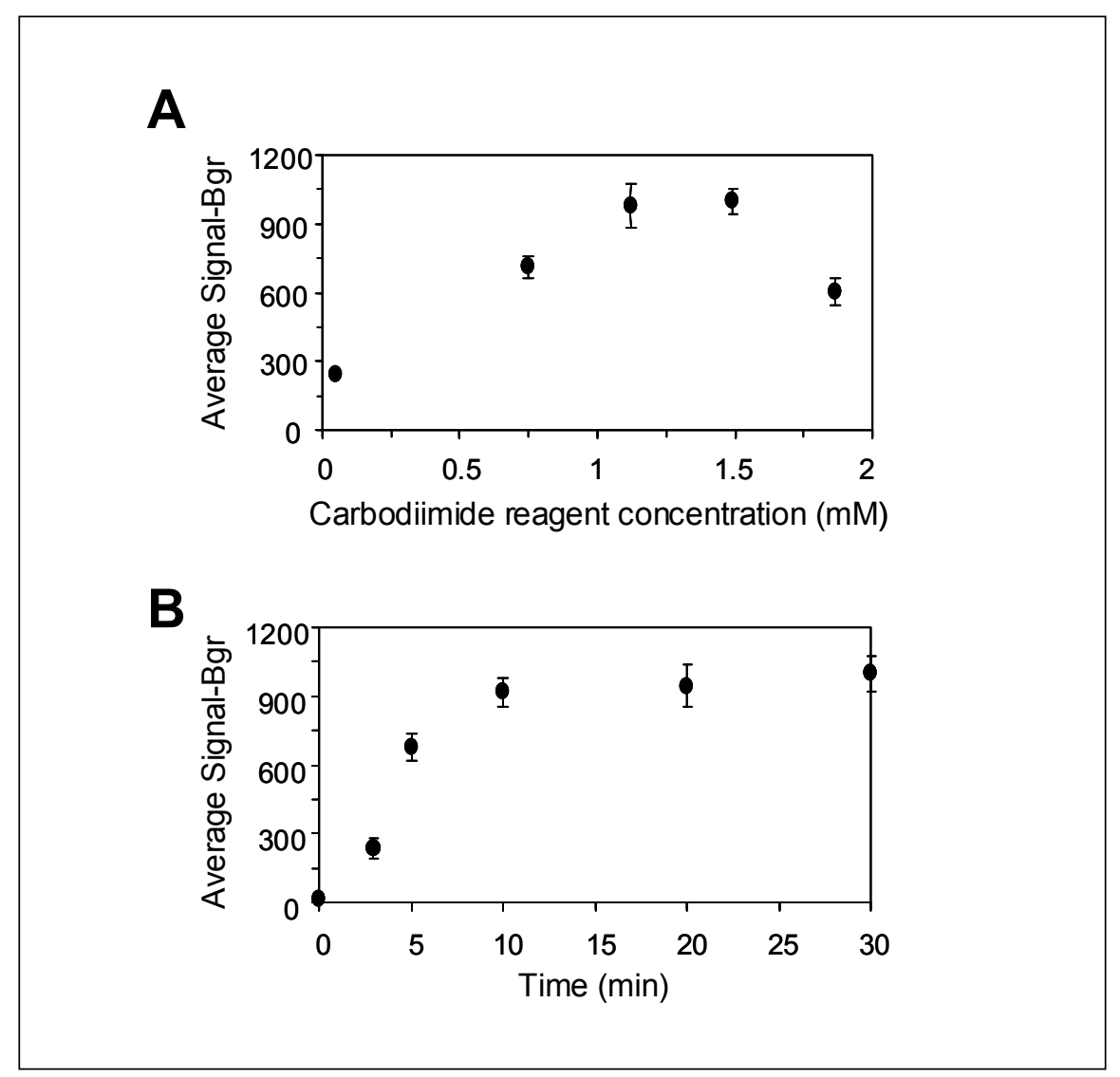

Figure 2. Effect of (A) carbodiimide concentration and (B) reaction time on hybridization efficiency. Reverse-transcribed cDNA from mouse liver total RNA $(5 \mu \mathrm{g})$ was labeled by Cy5-carbodiimide and hybridized to the oligonucleotide arrays. Each data point is the average of two hybridizations. The error bars indicate standard deviation. Bgr, background intensity. 
Table 2. Comparison of the $\log _{2}$ Fold Changes and Relative Signal Intensities Across all Platforms for Differentially Expressed Genes

\begin{tabular}{|c|c|c|c|c|c|c|c|}
\hline \multirow[b]{2}{*}{$\begin{array}{l}\text { GenBank } \\
\text { Accession No. }\end{array}$} & \multicolumn{2}{|c|}{ Carbodiimide } & \multicolumn{2}{|c|}{ Indirect } & \multicolumn{2}{|c|}{ Direct } & \multirow{2}{*}{$\begin{array}{c}\text { RT-PCR } \\
\text { Fold } \\
\text { Change }\end{array}$} \\
\hline & $\begin{array}{l}\text { Relative } \\
\text { Intensity }\end{array}$ & $\begin{array}{c}\text { Fold } \\
\text { Change }\end{array}$ & $\begin{array}{l}\text { Relative } \\
\text { Intensity }\end{array}$ & $\begin{array}{c}\text { Fold } \\
\text { Change }\end{array}$ & $\begin{array}{l}\text { Relative } \\
\text { Intensity }\end{array}$ & $\begin{array}{c}\text { Fold } \\
\text { Change }\end{array}$ & \\
\hline NM_008943 & 1.01 & 1.29 & 1.14 & -0.01 & 0.86 & -0.54 & N.A. \\
\hline NM_016700 & 0.84 & 1.28 & 0.86 & 1.12 & ND & ND & N.A. \\
\hline BC017516 & 0.83 & 1.18 & 0.91 & 0.95 & ND & ND & N.A. \\
\hline BC02189 & 1.07 & 1.16 & 1.04 & 0.26 & ND & ND & N.A. \\
\hline NM_007730 & 0.88 & 1.12 & 0.93 & 0.84 & ND & ND & N.A. \\
\hline BC003335 & 0.91 & 1.09 & 0.98 & 0.84 & 0.86 & 0.02 & N.A. \\
\hline NM_010048 & 0.99 & 1.07 & 1.06 & -0.29 & 0.87 & 0.96 & 2.56 \\
\hline NM_010080 & 1.08 & 1.01 & 1.13 & 1.37 & 0.99 & -0.56 & N.A. \\
\hline NM_008940 & 1.06 & 0.98 & 1.19 & 0.21 & 0.99 & 0.43 & 4.29 \\
\hline NM_020570 & 0.90 & 0.94 & 0.90 & 0.00 & ND & ND & -1.41 \\
\hline NM_009867 & 0.86 & 0.90 & 0.84 & 0.76 & ND & ND & N.A. \\
\hline NM_017373 & 1.01 & 0.86 & 0.99 & 0.21 & 0.94 & -0.40 & 3.89 \\
\hline NM_008139 & 0.84 & 0.79 & 0.99 & 0.43 & ND & ND & 1.24 \\
\hline NM_023653 & 0.84 & 0.50 & 0.96 & 1.01 & ND & ND & -3.44 \\
\hline NM_025278 & 0.97 & 0.30 & 0.96 & -0.15 & 1.02 & -1.47 & N.A. \\
\hline NM_009894 & 0.86 & 0.24 & 1.00 & 1.29 & ND & ND & 4.96 \\
\hline NM_010807 & 0.87 & 0.00 & 0.89 & -0.86 & ND & ND & 0.88 \\
\hline NM_010247 & 0.89 & -0.01 & 0.86 & -0.76 & 0.94 & -1.69 & -2.26 \\
\hline NM_031868 & 1.04 & -0.04 & 1.09 & -0.04 & 0.83 & -1.25 & N.A. \\
\hline NM_010343 & 0.99 & -0.38 & 1.01 & -0.79 & 0.97 & -0.54 & -7.89 \\
\hline Y12290 & 1.00 & -0.69 & 1.05 & -0.98 & 0.98 & -1.89 & N.A. \\
\hline AF302691 & 1.04 & -0.71 & 1.05 & -0.92 & 1.04 & -1.40 & N.A. \\
\hline BC021354 & 1.02 & -0.79 & 1.02 & -0.10 & ND & ND & N.A. \\
\hline NM_018792 & 0.84 & -0.92 & 0.82 & -1.43 & 0.95 & -0.15 & N.A. \\
\hline NM_009392 & 0.95 & -1.00 & 0.94 & -1.03 & 0.94 & 0.01 & N.A. \\
\hline NM_007811 & 0.95 & -1.03 & 0.97 & -0.25 & 0.93 & -0.04 & -7.61 \\
\hline NM_008494 & 0.99 & -1.03 & 0.93 & -0.81 & ND & ND & N.A. \\
\hline NM_018797 & 0.83 & -1.06 & 0.76 & -0.82 & ND & ND & N.A. \\
\hline NM_029632 & 1.11 & -1.06 & 1.06 & -1.29 & 1.00 & -0.92 & N.A. \\
\hline BC019986 & 0.99 & -1.06 & 0.86 & -0.79 & 0.93 & 0.01 & N.A. \\
\hline NM_008623 & 1.00 & -1.25 & 1.01 & -1.24 & 1.06 & -1.62 & N.A. \\
\hline NM_009453 & 1.09 & -1.32 & 1.02 & -1.40 & 1.14 & 0.48 & N.A. \\
\hline NM_011782 & 1.08 & -1.36 & 1.00 & -1.05 & 0.89 & -0.69 & N.A. \\
\hline
\end{tabular}

total RNA (1-5 $\mu \mathrm{g})$ were reverse-transcribed and labeled with either $\mathrm{Cy} 3$ or Cy5. These labeled cDNAs were then simultaneously hybridized to the oligonucleotide arrays for comparison. We measured backgroundsubtracted signal intensities for both dyes using three different labeling methodologies. Figure 3A shows that under identical hybridization and scanning conditions the signal intensities for both dyes arising from carbodiimide-labeled and aminoallyldUTP-labeled cDNA were comparable across the range of input mass of total RNA, whereas the signal intensities from cyanine-dUTP-labeled cDNA were 2- to 4-fold lower.

Next, we determined the accuracy and precision of competitive hybridization based on normalized $\mathrm{Cy} 3$ and Cy5 signals, measured after using different input amounts of mouse brain total RNA in the labeling process (Figure $3 \mathrm{~A}$ ). Approximately 5400 data points from three homotypic mouse brain hybridizations (5 $\mu \mathrm{g}$ each) were used to construct a histogram showing the frequency or distribution of gene elements (as a percentage of the total) around $\log _{2}$ of the expected ratios $\left(\log _{2} 1.0=0\right)$. Effectively, the histogram (Figure $3 \mathrm{~B}$ ) is a graphical measure of the range of the signal response for each element. We found that approximately $77.7 \%$ of the genes on the arrays generated with carbodiimide labeling were detected, and, among the genes detected, $98.8 \%$ showed less than a \pm 1.4 fold change in expression. In addition, the reproducibility of our labeling method was very high because the Pearson correlation coefficient for two independently 
labeled samples in $\log _{2}(\mathrm{Cy} 5)$ versus $\log _{2}(\mathrm{Cy} 3)$ plots indicated a very high correlation of between 0.97 and 0.98 . The coefficient of variation $(\mathrm{CV})$ of ratios for all elements was $12 \%$ across the entire signal range. Figure $3 \mathrm{~B}$ also shows that a similar trend was observed when we used the indirect labeling methodology. Approximately $74.5 \%$ of genes on the arrays generated with the indirect labeling method were detected and, among the genes detected, 96.8\% showed less than a \pm 1.4 -fold change in expression. The reproducibility of the two labeling methods was comparable because the Pearson correlation coefficient for two samples labeled independently by the indirect labeling methodology in $\log _{2}(\mathrm{Cy} 5)$ versus $\log _{2}(\mathrm{Cy} 3)$ plots also indicated a very high correlation of between 0.97 and 0.98 . The $\mathrm{CV}$ of ratios for all elements was $11 \%$ across the entire signal range. In our hands, however, the direct labeling methodology repeatedly gave signal intensities that were too insensitive and inaccurate for reliable hybridization assays within the range analyzed (data not shown), even with optimum PMT settings of the laser scanner, probably due to poor background-subtracted signal intensities (Figure 3A), which resulted in an increase in noise level. The results indicate that the accuracy and the precision of the carbodiimide and indirect labeling methods are comparable and clearly establish the reliability of our analytical system.

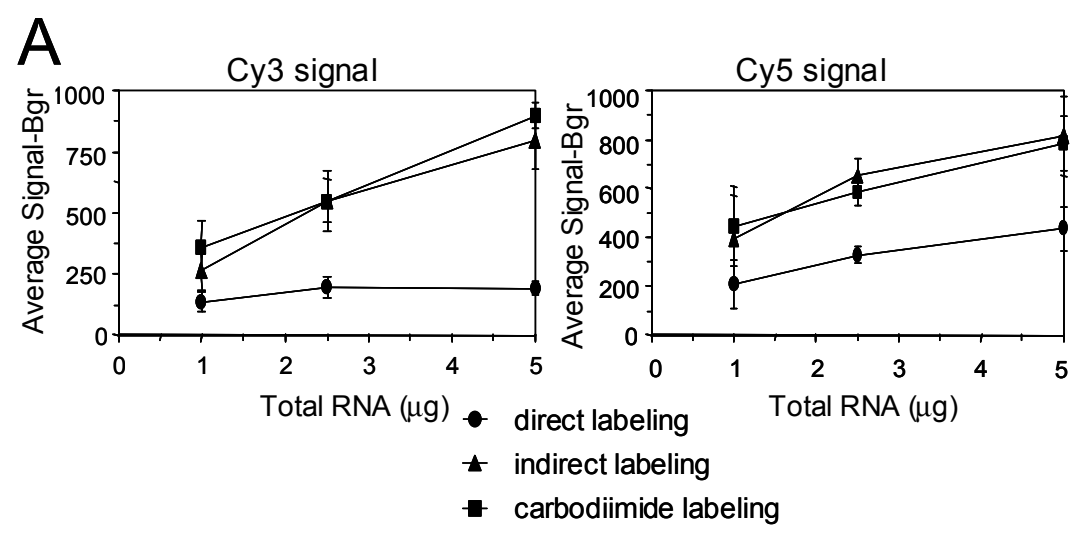

\section{B}
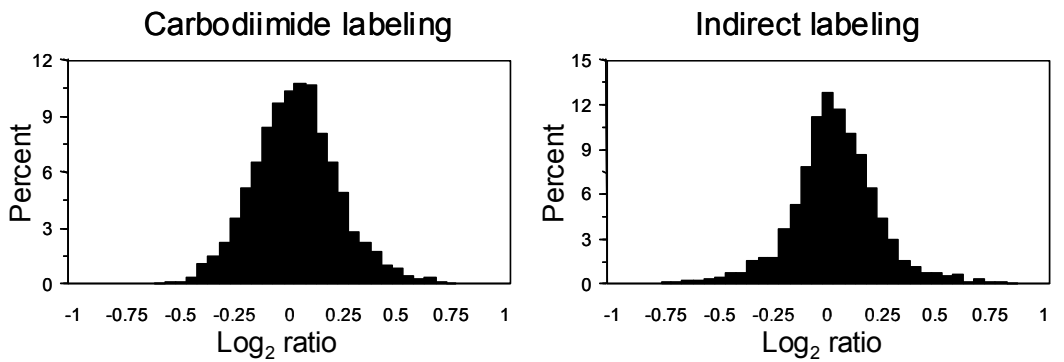

Figure 3. Comparison of hybridization data. (A) Average fluorescence signal intensities (backgroundsubtracted) shown as a function of the input mass of total RNA. The products from triplicate labeling reactions using Cy3- and Cy5-carbodiimide and cDNA resulting from increasing amounts of mouse brain total RNA were hybridized to 1794-element oligonucleotide arrays. Labeling reactions were performed using carbodiimide reagents $(1.2 \mathrm{mM})$ at $70^{\circ} \mathrm{C}$ for $10 \mathrm{~min}$. Each data point is the average of three hybridizations. Scanning was performed at the same laser power (100\%) and photomultiplier tube (PMT) settings $(60 \%)$ for both channels. The error bars indicate standard deviation. (B) Histogram showing the gene elements distributed according to the $\log _{2}$ value of their experimentally derived ratios for three homotypic brain hybridizations. In both cases, labeling reactions were done with the cDNA obtained from an input of $5 \mu \mathrm{g}$ total RNA. Bgr, background intensity.

Further studies were performed to determine the minimal amount of total RNA required for target labeling with our method. However, a reduction in input total RNA mass led to a reduction in the number of genes detected. The genes detected with our methodology corresponded to $75 \%$ of all elements for $2.5 \mu \mathrm{g}$ of input total RNA and $70 \%$ for $1 \mu \mathrm{g}$, respectively. The Pearson correlation coefficient for two independently labeled samples still indicated a high correlation, but it also tended to decrease as the input total RNA was reduced (i.e., between 0.89 and 0.97 for $2.5 \mu \mathrm{g}$ of input total RNA and between 0.88 and 0.92 for $1 \mu \mathrm{g}$, respectively), probably due to the decrease in the background-subtracted signal intensities (Figure 3A) and/or to the decrease in the number of low abundant transcripts that could be detected. A similar reduction was also observed when we used cDNA labeled by the indirect method (data not shown). 


\section{Differential Expression Analyses}

To assess the general performance of our carbodiimide labeling methodology in gene expression analysis, we performed a statistical test based on replicate microarray experiments to identify genes with an observed change in expression between mouse brain and liver tissue, and compared the results obtained with our methodology to those obtained with the indirect and direct labeling methodologies. In total, 18 separate microarray assays were conducted on two different samples of total RNA ( $5 \mu \mathrm{g}$ each) from two mouse tissues for each of the three labeling methodologies. In half of the replicate assays, the cDNA from mouse liver was labeled with the $\mathrm{Cy} 3$ dye, and the cDNA from mouse brain was labeled with the Cy5 dye; in the other half, the labeling scheme was reversed. Labeling reactions were performed using a 1.2$\mathrm{mM}$ concentration of the carbodiimide reagents at $70^{\circ} \mathrm{C}$ for $10 \mathrm{~min}$. Only those genes with good reproducibility $(P$ value $<0.05)$ and signal intensity above the threshold (see Materials and Methods) were considered differential.

Statistical analyses from multiple hybridization assays identified 25 genes that showed significant variation in expression by our methodology, 21 genes that showed significant variation by the indirect methodology, and only 6 genes that showed significant variation by the direct methodology (Figure 4). Among the genes detected by the three methodologies, however, we found that 16 of 30 genes matched between our method and the indirect labeling method, whereas only 2 of 29 genes matched between our method and the direct labeling method and only 3 of 24 genes matched between the direct and indirect labeling methods with optimum PMT settings of the laser scanner, although there were no genes that were up-regulated in one protocol and down-regulated in the other (Table 2).

To ascertain whether the expression changes observed for these divergent genes were biased by the absolute expression levels detected by either labeling methodology, we compared the relative intensity values of each of the genes for each labeling methodology.
As shown in Table 2, the intensity values of the divergent genes overall ranged around the median signal intensities observed in the carbodiimide and indirect methodologies. However, the direct labeling method failed to detect 13 of 31 divergent genes that were detected by the other two methodologies, even with optimum PMT settings of the laser scanner, probably due to its lower sensitivity, as shown in Figure $3 \mathrm{~A}$; thus, the expression changes for these divergent genes were not biased by signal intensities in the carbodiimide and indirect labeling methods.

More importantly, the results showed good within-platform reproducibility for the carbodiimide and the indirect labeling methodologies (the Pearson correlation coefficients between the fold ratios of all genes in replicate chips indicated a high correlation of $0.91-0.93$, and the average $\mathrm{CV}$ of ratios was approximately $14 \%$ across the entire signal range). For the direct labeling method, by contrast, the reproducibility is only moderate (the Pearson correlation coefficient gave a correlation of approximately 0.50 , and the average $\mathrm{CV}$ of ratios was $25 \%$ ). Thus, a major source of inconsistency among the three platforms, as shown in Figure 4 and Table 2, is simply caused by the insensitivity and/or significant variance of the direct labeling methodology, which can enhance the occurrence of false-positive or false-negative results.

\section{Confirmation of Differential Gene Expression}

To determine the effectiveness of our carbodiimide labeling methodology, we also verified the expression of a small set of genes by real-time fluorescent RTPCR. Real-time RT-PCR data of the 11 genes, along with the array data obtained using the three labeling methodologies, are shown in Table 2. In a few cases, no change could be assigned to the gene expression level in one of the systems. For the whole data set of 11 genes, there was a good correlation (correlation coefficient 0.73 ) between the changes reported by the two systems: the RT-PCR data and the microarray data obtained with our methodology. By contrast, there was only a low correlation (correlation coefficient 0.42 ) between the RT-PCR data and the microarray data obtained with the indirect labeling methodology for the genes analyzed, although the indirect labeling method showed good reproducibility in replicate assays as described above.

In this experiment, ratio compression on all array platforms in comparison to the RT-PCR platform was observed, similar to that described by Park et al. (21). Thus, depending on the genes being examined, the carbodiimide platform may also generate ratios that do not have the same magnitude as those of RT-PCR, although the trends (up- or down-regulation) are usually in good agreement.

Taken together, these results demonstrate the ability of the carbodiimide labeling method to reliably discern changes in gene expression.

\section{DISCUSSION}

We have evaluated the properties of two novel carbodiimide-based cyanine dyes with regard to their application to DNA microarrays. Although it is well known that a carbodiimide group reacts with unpaired thymine, guanine, or uracil bases in DNA or RNA $(13,14)$, to our knowledge this is the first study to demonstrate that these cyanine dyes can be applied successfully to gene expression analysis.

One might envision that labeled bases bearing the carbodiimide reagent could be hindered from forming hybridization duplexes because nucleotides

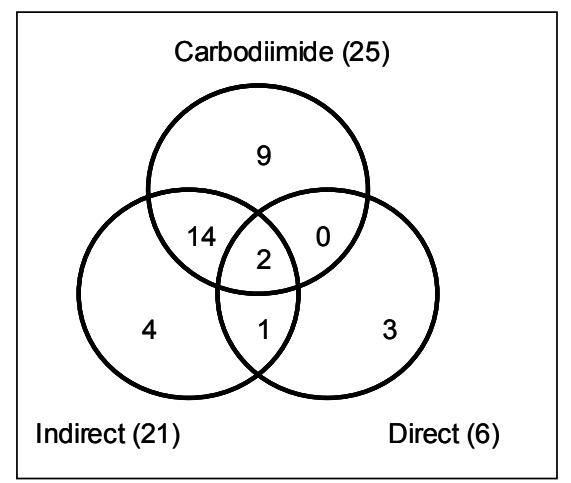

Figure 4. Venn diagram showing the number of differentially expressed genes in three labeling methodologies. The total number of differentially expressed genes determined by each methodology is indicated in parentheses. 
that have a keto group at the 4-position of the pyrimidine ring or at the equivalent 6-position of the purine ring will react with the carbodiimide to give the $\mathrm{N}$-substituted 3- or 1-adduct, respectively $(13,14)$, and/or to steric effects. Similarly, a previous study revealed that internal biotin labels attached via aminoallyl-dNTP subtly affect hybridization thermodynamics and duplex stability, and end-labeling of the DNA target enhances hybridization intensity (22). Nevertheless, we have shown that the carbodiimide-based cyanine dyes produce consistent data when repeatedly applied to analyses under the same conditions. The labeling efficiency of 30-50 bp per molecule of carbodiimide dye seems not to inhibit hybridization to an oligonucleotide array of 70-mers under the conditions used. Furthermore, the presence of a linker arm might alleviate the steric hindrance of the modified bases in DNA with carbodiimide reagents because a bulky cyanine dye can be attached to a carbodiimide group via the long linker arm (Figure 1). Indeed, there was a similar reduction in the hybridization intensity between cDNA labeled with our methodology and that labeled using the indirect method (data not shown) when we employed harsh washing conditions (ranging from $25^{\circ}-55^{\circ} \mathrm{C}$ ) after the hybridization step.

We also compared the carbodiimide chemical labeling methodology with two different conventional labeling methodologies for mouse cDNA. In self-on-self hybridization assays, our methodology showed 2- to 4-fold greater signal intensities than the conventional direct labeling methodology, and sensitivity and reproducibility comparable to those obtained with the indirect labeling methodology. This lower intensity was expected because the bulky cyanine moieties can be accommodated less easily than can the small aminoallyl moieties or nonmodified nucleotides during reverse transcription, which is in agreement with the higher degree of labeling achieved with aminoallyl-dUTPs than with cyanine-dUTPs (3-6). In contrast to previous reports (2-6), however, because we routinely used $5 \mu \mathrm{g}$ or less total RNA as input in each labeling reaction for the strict comparisons of each labeling methodology, it should be emphasized here that the optimal amount required for the direct labeling is usually at least 4-fold greater than that used in this study (2-6). Therefore, it is possible to achieve more reproducible and accurate hybridization assays for the direct labeling methodology when optimum amounts of total RNA are used.

In experiments for identifying genes that vary in expression between mouse brain and liver tissue, however, we found relatively low concordance between the genes showing expression changes by our labeling methodology and those showing changes by the indirect labeling methodology (16 of 30 genes, around 53\%), although our microarray results demonstrated that the carbodiimide and indirect labeling methodologies are both reliable for sample analysis. While we have not identified the cause of this discrepancy, features of the labeling method including (i) different cDNA synthesis protocols, (ii) different hybridization kinetics for aminoallyl-dUTP-incorporated cDNA and carbodiimide-labeled DNA molecules, and (iii) a cDNA labeling bias arising from the different chemistries probably contribute to the observed discordance (3-6). It should be emphasized here that the choice of the cDNA labeling method can critically affect the outcome of a microarray experiment. In addition, some genes detected by either methodology might not reach the statistically significant level (i.e., $P$ value $<0.05$ ) necessary to identify variable genes because of fluctuations in technical replicates. However, all DNA microarray hybridization data must be considered only as an initial global screening investigation. No experimental technique is perfect, and one has to find the best compromise of reliability, quality, and ease of use. Following microarray analysis, the expression levels of each 
gene target detected must be confirmed by other methods such as Northern blot analysis or RT-PCR analysis. Nonetheless, in our case, our study has shown for the genes examined, a good agreement in those showing significant changes in expression between our labeling method and the RT-PCR analysis, thereby indicating the ability of the carbodiimide labeling method to reliably discern changes in biology.

In conclusion, our current study demonstrates the utility of carbodiimide chemistry for DNA microarray analyses, suggesting that these carbodiimide reagents have the potential to become a powerful tool for monitoring changes in complex mRNA expression. Carrying out the labeling reactions in the presence of DMSO and/or at high temperatures (see Materials and Methods) results in nucleic acid unfolding, which can uniformly label cDNA such that labeling biases are minimal. Other advantages of this carbodiimide-mediated method include its simplicity and high speed, as with other chemical labeling methodologies $(11,12)$. According to this protocol, it takes only $10 \mathrm{~min}$ at $70^{\circ} \mathrm{C}$ to complete the cDNA labeling reaction. These advantages, together with high specificity of labeled nucleic acids in hybridization, make this method unique and highly promising for an alternative sample application to DNA microarray technology and automation. Furthermore, it is also possible to apply carbodiimide chemistry to the labeling and detection of RNA through its uracil or guanine base (14), and studies to optimize a labeling protocol with the reagents described in this study are currently underway. A labeling process based on these findings should assist in the development of high-quality arrays at an affordable price.

\section{ACKNOWLEDGMENTS}

The authors are grateful to Megumi Akiyama and Shougo Moriya for their technical assistance. We also gratefully acknowledge NAI, Inc. (Kanagawa, Japan) for their support in proofreading the manuscript and valuable suggestions.

\section{COMPETING INTERESTS STATEMENT}

N.K. is employed by Nisshinbo Industries, Inc., the manufacturer of a product mentioned in this article. The other authors declare no competing interests.

\section{REFERENCES}

1.Duggan, D.J., M. Bittner, Y. Chen, P. Meltzer, and J.M. Trent. 1999. Expression profiling using cDNA microarrays. Nat. Genet. 21(Suppl.):10-14.

2.Schena, M., D. Shalon, R.W. Davis, and P.O. Brown. 1995. Quantitative monitoring of gene expression patterns with a complementary DNA microarray. Science 270:465-470.

3.Stears, R.L., R.C. Getts, and S.R. Gullans. 2000. A novel, sensitive detection system for high-density microarrays using dendrimer technology. Physiol. Genomics 3:93-99.

4.Richter, A., C. Schwager, S. Hentze, W. Ansorge, M.W. Hentze, and M. Muckenthaler. 2002. Comparison of fluorescent tag DNA labeling methods used for expression analysis by DNA microarrays. BioTechniques 33:620-630.

5.Yu, J., M.I. Othman, R. Farjo, S. Zareparsi, S.P. MacNee, S. Yoshida, and A. Swaroop. 2002. Evaluation and optimization of procedures for target labeling and hybridization of cDNA microarrays. Mol. Vis. 8:130-137.

6.Xiang, C.C., O.A. Kozhich, M. Chen, J.M. Inman, Q.N. Phan, Y. Chen, and M.J. Brownstein. 2002. Amine-modified random primers to label probes for DNA microarrays. Nat. Biotechnol. 20:738-742.

7.Gullans, S.R. 2000. Of microarrays and meandering data points. Nat. Genet. 26:4-5.

8.Baldi, P. and A.D. Long. 2001. A Bayesian framework for the analysis of microarray expression data: regularized $t$-test and statistical inferences of gene changes. Bioinformatics 17:509-519.

9.Taniguchi, M., K. Miura, H. Iwao, and S. Yamanaka. 2001. Quantitative assessment of DNA microarrays-comparison with Northern blot analyses. Genomics 71:34-39.

10.Fillmore, G.C., Z. Lin, S.D. Bohling, R.S. Robetorye, C.-H. Kim, S.D. Jenson, K.S.J. Elenitoba-Johnson, and M.S. Lim. 2002. Gene expression profiling of cell lines derived from T-cell malignancies. FEBS Lett. 522:183-188.

11.Kelly, J.J., B.K. Chernov, I. Tovstanovsky, A.D. Mirzabekov, and S.G. Bavykin. 2002. Radical-generating coordination complexes as tools for rapid and effective fragmentation and fluorescent labeling of nucleic acids for microchip hybridization. Anal. Biochem. 311:103-118.

12.Heetebrij, R.J., E.G. Talman, M.A. van Velzen, R.P. van Gijlswijk, S.S. Snoeijers, M. Schalk, J. Wiegant, F. van de Rijke, et al. 2003. Platinum(II)-based coordination compounds as nucleic acid labeling reagents: synthesis, reactivity, and applications in hy- bridization assays. Chembiochem. 4:573-583.

13.Metz, D.H. and G.L. Brown. 1969. The investigation of nucleic acid secondary structure by means of chemical modification with a carbodiimide reagent. I. The reaction between $\mathrm{N}$-cyclohexyl-N'- $\beta$-(4-methylmorpholinium) ethylcarbodiimide and model nucleotide. Biochemistry 8:2312-2328.

14.Metz, D.H. and G.L. Brown. 1969. The investigation of nucleic acid secondary structure by means of chemical modification with a carbodiimide reagents. II. The reaction between $\mathrm{N}$-cyclohexyl-N'- $\beta$-(4-methylmorpholinium)ethylcarbodiimide and transfer ribonucleic acid. Biochemistry 8:2329-2342

15.Masuda, G., N. Shiohata, T. Ichihara, K. Matsumoto, S. Takenishi, and O. Suzuki. 1995. New biotinylating reagent utilizing carbodiimide function. Nucleic Acids Symp. Ser. 34:69-70.

16.Kimura, N., R. Oda, Y. Inaki, and O. Suzuki. 2004. Attachment of oligonucleotide probes to poly carbodiimide-coated glass for microarray applications. Nucleic Acids Res. 32:e68.

17.Wang, X. and B. Seed. 2003. Selection of oligonucleotide probes for protein coding sequences. Bioinformatics 19:796-802.

18.Mujumdar, R.B., L.A. Ernst, S.R. Mujumdar, C.J. Lewis, and A.S. Waggoner. 1993. Cyanine dye labeling reagents: sulfoindocyanine succinimidyl esters. Bioconjugate $\mathrm{Chem}$. 4:105-111.

19.Wittwer, C.T., K.M. Ririe, R.V. Andrew, D.A. David, R.A. Gundry, and U.J. Balis. 1997. The LightCycler: a microvolume multisample fluorometer with rapid temperature control. BioTechniques 22:176-181.

20.Wittwer, C.T., M.G. Herrman, A.A. Moss, and R.P. Rasmussen. 1997. Continuous fluorescence monitoring of rapid cycle DNA amplification. BioTechniques 22:130-138.

21.Park, P.J., Y.A. Cao, S.Y. Lee, J.W. Kim, M.S. Chang, R. Hart, and S. Choi. 2004. Current issues for DNA microarrays: platform comparison, double linear amplification, and universal RNA reference. J. Biotechnol. 112:225-245.

22.Cook, A.F., E. Vuocolo, and C.L. Brakel. 1988. Synthesis and hybridization of a series of biotinylated oligonucleotides. Nucleic Acids Res. 16:4077-4095.

Received 18 October 2004; accepted 11 January 2005.

\section{Address correspondence to:}

Naoki Kimura

Research and Development Center

Nisshinbo Industries, Inc.

1-2-3 Ohnodai, Midori-ku, Chiba-shi

Chiba 267-0056, Japan

e-mail: n-kimu@nisshinbo.co.jp 